NISTIR 88-3901

\title{
MICROPOROUS FUMED-SILICA \\ INSULATION BOARD AS A CANDIDATE STANDARD REFERENCE MATERIAL OF THERMAL RESISTANCE
}

David R. Smith

Jerome G. Hust

National Institute of Standards and Technology

(formerly National Bureau of Standards)

U.S. Department of Commerce

Boulder, Colorado 80303-3328

October 1988

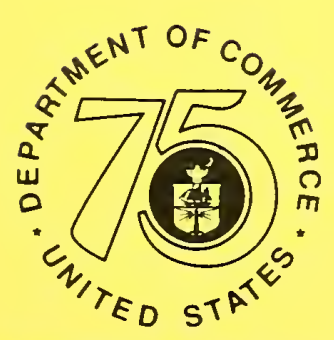

Stımulating America's Progress 



\section{MICROPOROUS FUMED-SILICA} INSULATION BOARD AS A CANDIDATE STANDARD REFERENCE MATERIAL OF THERMAL RESISTANCE

David R. Smith Jerome G. Hust

Chemical Engineering Science Division Center for Chemical Engineering National Engineering Laboratory National Institute of Standards and Technology Boulder, Colorado 80303-3328

October 1988

Sponsored, in part, by U.S. Department of Energy Oak Ridge National Laboratory

Oak Ridge, Tennessee 37830

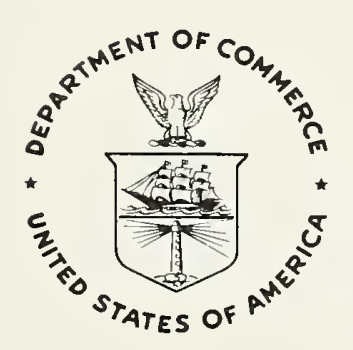

U.S. DEPARTMENT OF COMMERCE, C. William Verity, Secretary NATIONAL INSTITUTE OF STANDARDS AND TECHNOLOGY, Ernest Ambler, Director 

CONTENTS

LIST OF TABLES $\ldots \ldots \ldots \ldots \ldots \ldots \ldots \ldots \ldots \ldots \ldots \ldots \ldots \ldots \ldots \ldots$

LIST OF FIGURES $\ldots \ldots \ldots \ldots \ldots \ldots \ldots \ldots \ldots \ldots \ldots \ldots$

ABSTRACT $\ldots \ldots \ldots \ldots \ldots \ldots \ldots \ldots \ldots \ldots \ldots \ldots \ldots \ldots \ldots \ldots \ldots$

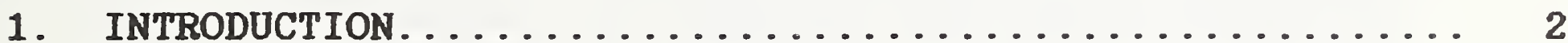

2. CHARACTERIZATION OF MATERIAL.................. 3

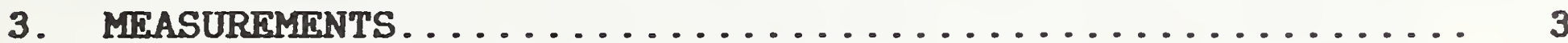

4. DATA ANALYSIS AND DISCUSSION .................. 5

A. Thermal Conductivity as a Function of Temperature... 5

B. Thermal Conductivity as a Function of Pressure..... 6

5. COMPARISIONS............................ 8

6. RECOMENDATIONS ......................... 10

7. REFERENCES .............................. 11 


\section{LIST OF TABLES}

Table 1. Thermal conductivity of a pair of microporous fumedsilica insulation boards with a mean density of $301 \mathrm{~kg} / \mathrm{m}^{3}$, at mean temperatures from 321 to $723 \mathrm{~K}$ $(48$ to $450 \circ \mathrm{C})$. Measurements were performed in air at ambient humidity and at a pressure of $83.6 \mathrm{kPa}$ (627 Torr), using the high-temperature guarded hot plate at the National Institute of Standards and Technology in Boulder, Colorado. Temperature differences through the specimens were chosen to be about 10 percent of the value of the mean temperature within the specimens. The bias in values of $K m e a s$ is estimated to be 1.5 percent at $330 \mathrm{~K}$, and 2.5 percent at $720 \mathrm{~K}$. Deviations compare measured thermal conductivity to values of Kcalc computed from eq (1)... 12

Table 2. Thermal conductivity of a pair of microporous fumedsilica insulation boards with a mean density of 301 $\mathrm{kg} / \mathrm{m}^{3}$, at a mean temperature of $318 \mathrm{~K}(45 \circ \mathrm{C})$. Measurements were performed in air at ambient humidity and at pressures ranging from 40 to $83.5 \mathrm{kPa}$ (626 Torr) using the NIST/B high-temperature guarded hot plate. Temperature differences through the specimens were chosen to be about 10 percent of the value of the mean temperature within the specimens. The bias in values of Kmeas is estimated to be 1.5 percent at $330 \mathrm{~K}$. Deviations compare measured thermal conductivity to values of Kealc, computed from eq (2). The highest pressure ( $83.5 \mathrm{kPa} ; 626$ Torr) is the local ambient atmospheric pressure at Boulder, Colorado............................. 13 


\section{LIST OF FIGURES}

Figure 1. Thermal conductivity of a pair of microporous fumed-silica insulation boards with a mean density of $301 \mathrm{~kg} / \mathrm{m}^{3}$, at mean temperatures from 321 to 723 $\mathrm{K}$ ( 48 to $450 \circ \mathrm{C})$. Measurements were performed in air at ambient humidity and at a pressure of 83.6 $\mathrm{kPa}$ (627 Torr) using the NIST/B high-temperature guarded hot plate. The measurement bias in values of Kmeas is estimated to be 1.5 percent at $330 \mathrm{~K}$, and 2.5 percent at $720 \mathrm{~K}$. The solid curve represents values of $\mathrm{Kealc}$, obtained using eq (1)...... 14

Figure 2. Deviations of thermal conductivity of microporous fumed-silica specimens from values calculated with

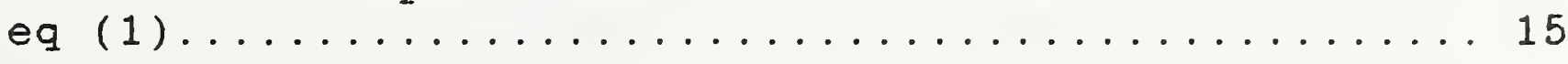

Figure 3. Thermal conductivity of a pair of microporous fumed-silica insulation boards with a mean density of $301 \mathrm{~g} / \mathrm{m}^{3}$, at a mean temperature of $318 \mathrm{~K}(45 \circ \mathrm{C})$. Measurements were performed in air at ambient humidity and at pressures varying from 40 to $83.5 \mathrm{kPa}$ ( 300 to 626 Torr). The solid line was calculated

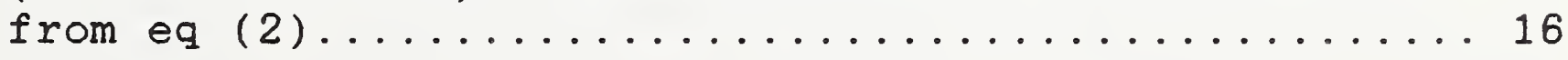

Figure 4. Deviations of thermal conductivity of microporous fumed-silica specimens from values calculated with

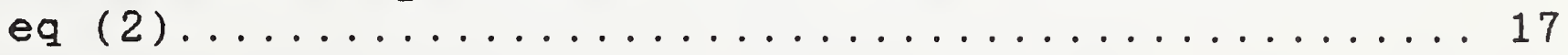

Figure 5. Extrapolated correlation of thermal conductivity with pressure, eq (2), estimating thermal conductivity of microporous fumed-silica insulation at sealevel atmospheric pressure $(101.3 \mathrm{kPa})$ as indicated by the open circle at the top. Mean temperature of

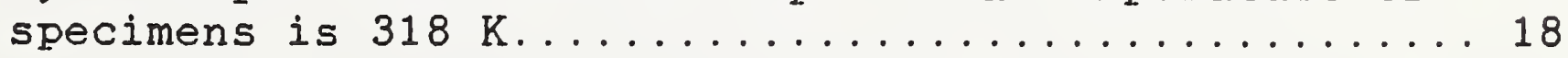



Microporous Fumed-Silica Insulation Board

as a Candidate Standard Reference Material

of Thermal Resistance

\author{
David R. Smith \\ and \\ Jerome G. Hust \\ Chemical Engineering Science Division \\ National Engineering Laboratory \\ National Institute of Standards and Technology \\ Boulder, CO 80303-3328
}

Measurements of apparent thermal conductivity of microporous fumed-silica insulation board are reported in order to provide a basis for certifying it as a Standard Reference Material (SRM) of thermal resistance. These data, for a pair of specimens having a mean density of $301 \mathrm{~kg} / \mathrm{m}^{3}$, encompass a range of temperature from 321 to $723 \mathrm{~K}$ and environmental gas pressures at and below ambient atmospheric pressure (40 to $83.7 \mathrm{kPa}$ ). Detailed analyses and intercomparisons of previously published data are given. Correlations of thermal conductivity with temperature and with pressure are given which represent the data within a standard deviation of $0.2 \%$. This fumed-silica material has a thermal conductivity of $19.68 \mathrm{~mW} /(\mathrm{m} \cdot \mathrm{K})$ at $300 \mathrm{~K}$ and is suitable for use as an SRM of very low conductivity from room temperature up to temperatures beyond $720 \mathrm{~K}(450 \circ \mathrm{C})$. Great care in handling this material is necessary because of its fragility.

Key words: apparent thermal conductivity; density; microporous fumed silica; pressure; Standard Reference Material; temperature; thermal insulation; thermal resistance.

This work was funded, in part, by DOE/ORNL under contract ORNL/IA21428 . 


\section{INTRODUCTION}

The Office of Standard Reference Materials of the U.S. National Institute of Standards and Technology, NIST, (formerly the National Bureau of Standards, NBS) establishes Standard Reference Materials (SRMs) to improve reliability in measurement of physical properties. Specifically, SRMs of thermal resistance are used by industrial, academic, and government laboratories to verify the correct operation of guarded hot plates (GHPs) and to calibrate instruments such as heat-flow meters. These instruments measure the rate of heat flow under given temperature differences through specimens of known thickness. From such data one can obtain the thermal resistance (Rvalue) of the measured specimen, as well as the thermal conductivity (or its reciprocal, the resistivity) of the homogeneous material. SRMs can also be used to indicate the accuracy of measurement of apparent conductivity of thermally conducting materials over a range of parameters such as bulk density, temperature, and environmental air pressure. The Properties of Solids Group within the Chemical Engineering Science Division of NIST in Boulder, Colorado, (NIST/B) has participated for about 25 years in establishing SRMs of thermal resistance over a broad range of thermal conductivity, pressure, and temperature. The status of this effort has been summarized by Hust [1].

During the mid-1970's, the American Society for Testing and Materials (ASTM) recognized the great need for thermal insulation SRMs. Consequently, a task-group was established under the auspices of ASTM subcommittee $\mathrm{C} 16.30$ on thermal measurements. Recommendations for establishing thermal insulation SRMs were published in 1978 [2].

No SRM of thermal resistance for use at temperatures above 330 $K$ is available at the present time from the Office of Standard Reference Materials of NIST in Gaithersburg, Maryland (NIST/G), in spite of the very strong need for such SRMs.

We report measurements of apparent thermal conductivity of one pair of specimens of microporous fumed-silica insulation board. This pair was obtained from the Heat Transfer Group of the Center for Building Technology at NIST/G, which is certifying one lot of this material as an SRM at room temperature. This material was investigated because of the recommendations of the ASTM C16.30 committee and of an advisory panel composed of representatives from government and industry. Additional measurements are currently being performed at NIST/B and NIST/G on several other specimen pairs of similar material, more fully to characterize its properties. Workers at NIST/G are measuring additional specimens with their 1meter GHP, at environmental pressures very near $101.3 \mathrm{kPa}$, and at a temperature of $297 \mathrm{~K}$. Work at NIST/B involves study of a selected subset of these specimens, with measurements of thermal conductivity performed over a greater range of temperature and pressure than is possible with the 1-meter apparatus. 


\section{CHARACTERIZATION OF MATERIAL}

This insulation material is produced as rigid boards of bonded silica-aerogel composite made of very fine particles of synthetic amorphous silica, opacifier, fine ceramic fibers, and a binder $[3,4]$. The size of the silica particles has been reported by the manufacturer to be approximately $10^{-8} \mathrm{~m}$. The fine ceramic fibers increase the cohesiveness of the board, and the binder cements the surfaces of the particles and fibers together into a cellular structure by sintering when the boards are cured at high temperatures $(9000 \mathrm{C})$. Ilmenite $(\mathrm{FeO} . \mathrm{TiO})$ is the opacifier added to reduce radiative heat transmission through the board for use at high temperatures. The fractions of silica particles, opacifier, and ceramic fiber stand approximately in the ratios 60:35:5. All organic matter is burned out in curing.

Microporous fumed-silica insulation board in its raw-product form is very fragile and must be handled with great care. The edges of the slabs are easily chipped during installation and removal from the measurement apparatus. Boards having an edge dimension longer than about $30 \mathrm{~cm}$ are easily damaged during handling and shipping unless great care is taken to support them over a whole face and to protect them from localized impacts. However with proper cushioning of the specimens when they are packed for shipping, and with proper support of the broad faces when they are installed in an apparatus, a careful worker can probably measure them 20 or 30 times without significant degradation of their surfaces due to chipping or breaking. Great care will be necessary in handling these specimens.

An evaluation lot comprising 10 specimens of this material was originally obtained by NIST/G [4]. The specimens as received were about $2.5 \mathrm{~cm}$ in thickness and $60 \mathrm{~cm}$ square. After measurements of thermal conductivity were performed in the 1 -meter GHP at NIST/G, a selected pair of specimens was cut into $30 \mathrm{~cm}$ squares and shipped to NIST/B. Two specimens for which thermal conductivity measurements are reported here had a mean density of $301 \mathrm{~kg} / \mathrm{m}^{3}\left(18.8 \mathrm{lbm} / \mathrm{ft}^{3}\right)$.

\section{MEASUREMENTS}

For brevity, we shall use the term "thermal conductivity" to denote the term "apparent thermal conductivity" in the following text. Analysis of our data in the following section suggests that radiative heat transfer in this microporous fumed-silica board is not negligible, but, near room temperature, contributes only a small amount in comparison to conductive heat transfer. Because of the density and microporosity of this material, convective heat transfer is totally negligible. Thermal conductivity is therefore an appropriate descriptor of the heat-transfer behavior of this material over the temperature range studied. 
The thermal conductivity data reported here were obtained with the high-temperature guarded hot plate described by Hust, Filla, Hurley, and Smith [5]. The diameter of this circular hot-plate stack is $25 \mathrm{~cm}$ (10 in), and the area of the metered main heater has a diameter of $12.5 \mathrm{~cm}$ ( 5 in).

The specimens were received as square slabs nominally $300 \mathrm{~mm}$ on a side. The measurement apparatus requires disks $250 \mathrm{~mm}$ in diameter, so disks were cut from the square slabs by using a bandsaw set to a low cutting speed. The material is very easily cut and the disk was not damaged during the cutting. The annular material making up the rest of the square is sometimes split during the cutting, however. Because the material generates air-borne dust during machining operations, prudence requires the use of a dust mask by the person cutting this material. Although the material from which the insulation is manufactured is not toxic, the dust is very fine and is borne by stray air currents over distances of several meters.

We measured the thickness of each specimen using a digital electronic caliper with a precision of $0.03 \mathrm{~mm}(0.001 \mathrm{in})$. Measurements of thickness were made at eight locations equally spaced around the perimeter of the disk, and the measurements were averaged. The standard deviation of the thickness measurements is $0.08 \mathrm{~mm}$ for a nominal specimen thickness of $25 \mathrm{~mm}$ (relative standard deviation of $0.3 \%$ ).

Using a steel ruler that had a precision of $0.25 \mathrm{~mm}$, we measured the diameter of each specimen along four different directions, and the results averaged. The standard deviation of these measurements was $0.8 \mathrm{~mm}$ for a nominal diameter of $255 \mathrm{~mm}$ (relative standard deviation of $0.3 \%$ ).

Masses of the specimens were measured on a laboratory trip balance with a sensitivity of $0.1 \mathrm{~g}$ for a typical mass of about $400 \mathrm{~g}$ (relative imprecision of $0.03 \%$ ).

The density can be determined from these measurements with a precision of $\pm 0.5 \%$. The mass of each specimen decreased by about 3 f from conditioning in an oven at $900 \mathrm{C}$ before the thermal conductivity was measured, and then increased by about 2 g during the measurement, as revealed by the mass of the specimen upon removal from the apparatus. These changes in mass due to the rigors of conditioning and measurement amount to about $0.8 \%$ uncertainty in the density. 
After the specimens were installed in the apparatus they were heated to the highest temperature of measurement before the thermal conductivity was measured. There is no evidence in the thermal conductivity data that phase changes occur in the material below $4750 \mathrm{C}$, the highest temperature to which the specimens (that is, their sides adjacent to the hot main plate) were exposed during measurements. There does seem to be some adsorption of moisture, which must be driven off before measurements are stable. We found it necessary to repeat measurements two or more times at a given mean temperature until the values obtained did not vary by more than the experimental reproducibility ( $0.5 \%$ for this apparatus).

The thermal conductivity of this pair of specimens was measured at mean temperatures up to $723 \mathrm{~K}(4500 \mathrm{C})$ with air at ambient pressure and humidity in the environmental chamber. Absolute temperatures and temperature differences were stabilized and measured with a precision of $0.02 \%$. The precision of the measurement of thermal conductivity was estimated to be $0.5 \%$ at $330 \mathrm{~K}$, and $0.7 \%$ at $720 \mathrm{~K}$. The bias was estimated to be $1.5 \%$ at $330 \mathrm{~K}$ and $2.5 \%$ at $720 \mathrm{~K}$.

In table 1 we list 38 measurements of thermal conductivity for this pair of microporous fumed-silica insulation boards in air at a pressure of $83.6 \mathrm{kPa}$ ( 627 Torr) and at mean temperatures varying from 321 to $723 \mathrm{~K}(48$ to $4500 \mathrm{C})$.

In order to obtain the effect of the environmental gas pressure on the thermal conductivity, we measured this pair at selected environmental air pressures evenly spaced over the range from $40.0 \mathrm{kPa}$ ( 300 Torr) to $83.5 \mathrm{kPa}$ (626 Torr). The measurements of thermal conductivity at these pressures were made at a constant mean temperature of $318 \mathrm{~K}(45 \circ \mathrm{C})$. Gas pressure was measured with a precision of $0.13 \mathrm{kPa}(0.1$ Torr; a relative precision of $0.3 \%$ at the lowest pressure). The inaccuracy of pressure measurements is about 1\%. The 20 measurements from these experiments are listed in table 2.

\section{DATA ANALYSIS AND DISCUSSION}

A. Thermal Conductivity as a Function of Temperature

The 38 data points in table 1 were analyzed to determine the correlation of thermal conductivity with mean specimen temperature. The thermal conductivity over the temperature range $321<\mathrm{T}<723 \mathrm{~K}$, for the pair of specimens with a density of $301 \mathrm{~kg} / \mathrm{m}^{3}$ and in an environment of air at a pressure of $83.6 \mathrm{kPa}$ and ambient humidity, was represented by

$$
\mathrm{k}=18.46+2.283 * 10-3 \mathrm{~T}+1.983 * 10-8 \mathrm{~T}^{3},
$$


where $\mathrm{k}$ is in $\mathrm{mW} /(\mathrm{m} \cdot \mathrm{K})$ and $\mathrm{T}$ is in $\mathrm{K}$. This correlation was obtained using a weighted least-squares fit and the thermal conductivity integral (TCI) method [6].

The curve in figure 1 representing the thermal conductivity as a function of temperature is seen to have very little curvature. Also, relatively small temperature differences were imposed on the specimens during these measurements. Thus it would not be necessary to use the TCI method to fit these data. The TCI method is indicated for use whenever measurements are made with large differences in the boundary temperatures of the specimen and with appreciable curvature in the thermal conductivity function over the included range of temperature. However, we always use the TCI method as a matter of course, whether or not the data seem to have enough curvature to require the method. This ensures that no additional errors are ever introduced by our fitting procedure due to nonlinearity in the fitted function.

The 38 thermal conductivity data kmeas used to determine this dependence of $k$ on temperature are plotted as open circles in figure 1; the correlation given by $e q(1)$ is plotted in figure 1 as the solid line. The deviations of the data from values of kealc computed from $e q(1)$ are plotted in figure 2 and are listed in the last column of table 1 . The standard deviation of the data from the fitted curve is $0.21 \%$.

The curvature of the solid line in figure 1 is correlated with the $T^{3}$ term in eq(1), which, being nonlinear, grows larger relative to the other two terms with increasing temperature. This T3 term is related to the contribution of radiative heat transfer to the total heat transfer through the material. At $297 \mathrm{~K}$ the magnitude of this term is $0.5 \mathrm{~mW} /(\mathrm{m} \cdot \mathrm{K})$ out of a total apparent conductivity of 19.7 $\mathrm{mW} /(\mathrm{m} \cdot \mathrm{K})$, or $2.6 \%$ of the total. At $700 \mathrm{~K}$ the magnitude of the $\mathrm{T}^{3}$ term is $6.8 \mathrm{~mW} /(\mathrm{m} \cdot \mathrm{K})$ out of a total of $26.9 \mathrm{~mW} /(\mathrm{m} \cdot \mathrm{K})$, or $25.3 \%$ of the total. Thus in this range of temperature, the radiative contribution to the total heat transfer is becoming appreciable.

\section{B. Thermal Conductivity as a Function of Pressure}

The correlation of thermal conductivity with pressure $P$ was obtained from the 20 data points listed in table 2, for a mean specimen temperature of $318 \mathrm{~K}(450 \mathrm{C})$, a temperature difference within the specimen no greater than $30 \mathrm{~K}$, and a density of $301 \mathrm{~kg} / \mathrm{m}^{3}$. By use of a weighted least-squares fit the correlation was represented by

$$
\mathrm{k}=9.337+0.17436 \mathrm{P}-5.6095 * 10^{-4} \mathrm{P} 2
$$


where $\mathrm{k}$ is in $\mathrm{mW} /(\mathrm{m} \cdot \mathrm{K})$ and $\mathrm{P}$ is in $\mathrm{kPa}$; this relation is valid over the range of pressure from 40 to $83.5 \mathrm{kPa}$. Because the pressure is constant throughout the specimen, it is not necessary to use the TCI method to fit this correlation with pressure. For the relatively small temperature difference used ( $30 \mathrm{~K})$, any error made by associating the thermal conductivity with the mean temperature of the specimen is inappreciable.

The thermal conductivity data used to determine this dependence of $\mathrm{k}$ on pressure are plotted as open squares in figure 3 ; the correlation given by $e q(2)$ is plotted in figure 3 as the solid line. Deviations of the data from values of kcalc computed from eq(2) are plotted in figure 4 and are also listed in the last column of table 2 . The standard deviation of the data from this curve is also $0.21 \%$.

The maximum value of $\mathrm{kcalc}, 19.98 \mathrm{~mW} /(\mathrm{m} \cdot \mathrm{K})$, given in table 2 , represents the value of thermal conductivity $\mathrm{kB}$ at the ambient atmospheric pressure at Boulder, Colorado. At this elevation, approximately $1650 \mathrm{~m}$, or $5400 \mathrm{ft}$, above sea level, the atmospheric pressure is 83.3, with normal fluctuations, due to local weather, of $\pm 0.5 \mathrm{kPa}$. By extrapolation of eq(2) to a condition of one standard atmosphere of pressure, $101.3 \mathrm{kPa}$ (corresponding to sea level), the thermal conductivity $k s \mathrm{l}$ is estimated to be $21.245 \mathrm{~mW} /(\mathrm{m} \cdot \mathrm{K})$. This value is compared with the data for pressure dependence by representing it as the circle in figure 5. This value is $6.3 \%$ higher than the value $k B=19.98$, obtained for our laboratory in Boulder. That is, the ratio of the two values is $\mathrm{ks} / \mathrm{kB}=1.063$. This factor will be of use in the next section comparing these data with the results of measurements on this same lot of material by workers at $\mathrm{NIST/G}$, at sea level.

Because the form of the $k$ dependence given by eq(2) is nonlinear (quadratic dependence on $P$ ), the rate of change of $k$ with pressure changes with pressure. Figure 2 shows that the slope of $k$ versus $P$ is steeper at lower pressures and less steep at higher pressures. For this fumed-silica insulation the rate of change of $k$ with pressure $P$, or slope of the $k(P)$ function plotted in figure 2 , is given by the mathematical first derivative of the $k(P)$ function:

$$
\mathrm{dk} / \mathrm{dP}=0.17436-2 * 5.6095 * 10^{-4} \mathrm{P} .
$$

At sea level, where $P_{s l}=101.325 \mathrm{kPa}$, the rate of change of $k$ with pressure takes the value 0.0607 , which is also the slope of the $k(P)$ relation, eq(2), at $P_{s}$. At the elevation of our laboratory at Boulder, where the pressure is $\mathrm{PB}=83.5 \mathrm{kPa}$, the rate of change of $k$ with pressure is 0.0807 , which is the slope of the $k(P)$ relation, eq(2), at PB. But because these slopes are different, neither of them is valid for extrapolating values of $k$ to a different range of pressure. Rather, the $k(P)$ relation itself, given by eq(2), should be used. 


\section{COMPARISONS}

A similar microporous material of low thermal conductivity, with a nominal density of about $310 \mathrm{~kg} / \mathrm{m}^{3}$, was studied by Tye [7]. Its thermal conductivity ranged from $26.5 \mathrm{~mW} /(\mathrm{m} \cdot \mathrm{K})$ at $250 \mathrm{C}$ to 48.5 $\mathrm{mW} /(\mathrm{m} \cdot \mathrm{K})$ at $650 \circ \mathrm{C}$. He recommended in 1970 that it be considered as a possible SRM.

Microporous fumed-silica insulation board has been investigated for use as a possible SRM of low thermal conductivity by Rennex, Somers, Faison, and Zarr [3], and by Zarr, Somers and Ebberts [4] at NIST/G. All but two of the latter set of measurements were performed at a mean specimen temperature of $297 \mathrm{~K}\left(24^{\circ} \mathrm{C}\right)$ and at a pressure of $101.33 \mathrm{kPa}$ (760 Torr), on specimens having densities ranging from 310 to $333 \mathrm{~kg} / \mathrm{m}^{3}$. The apparatus used at NIST $/ \mathrm{G}$, a GHP with a diameter of $1 \mathrm{~m}$, is enclosed in a rectangular environmental chamber with dimensions larger than $1 \mathrm{~m}$. Thus this apparatus is limited by its size and geometry to a very small range of environmental gas pressure, around ambient barometric pressure, that can be safely used within it. The present measurements extend the range of correlation of thermal conductivity for microporous fumed silica insulation to the temperature interval from 318 to $723 \mathrm{~K}(45$ to $4500 \mathrm{C})$. The correlation is also exterided to environmental gas pressures over the range from 40 to $83 \mathrm{kPa}$ ( 300 to 626 Torr).

The microporous insulation material had a somewhat lower conductivity than that of the material studied by Tye. Rennex, Somers, Faison and Zarr [3], found that the thermal conductivity of this material at a temperature of $297 \mathrm{~K}$ could be represented by the correlation

$$
k=21.94+0.03076(D-301.4)+0.09936(P-101.33)
$$

where $\mathrm{k}$ is conductivity in $\mathrm{mW} /(\mathrm{m} \cdot \mathrm{K}), \mathrm{D}$ is density in $\mathrm{kg} / \mathrm{m}^{3}$, and $\mathrm{P}$ is pressure in $\mathrm{kPa}$.

The coefficient, 0.09936 , of the pressure term in eq(4), is the rate of change of thermal conductivity with pressure, or slope of a plot of $k$ versus $P$, for a specimen at a temperature of $297 \mathrm{~K}$ and an environmental gas pressure of $101.3 \mathrm{kPa}$. This coefficient was obtained over the range of pressures from 99.3 to $101.2 \mathrm{kPa}$. This value compares with the value of 0.0607 obtained by extrapolating eq(3), the relation for the slope of $\mathrm{k}$ against $\mathrm{P}$, to $P_{0}=101.3 \mathrm{kPa}$. A full understanding of the disagreement between the two slopes of $k(P)$ obtained by the two different laboratories has yet to be obtained. According to the NIST/G group, however, moisture content has a slight but measurable effect on thermal conductivity at $297 \mathrm{~K}$, and this variable was not controlled by either lab for the results reported here. 
However, extrapolating eq(1) to a value of $T=297 \mathrm{~K}$, only slightly below the lowest temperature used by us in obtaining this correlation, we estimate that $\mathrm{k}=19.66 \mathrm{~mW} /(\mathrm{m} \cdot \mathrm{K})$ is the value of thermal conductivity for our fumed-silica specimens at $297 \mathrm{~K}$, that would be measured in the Boulder lab. We estimated in the previous section that the effect of increasing the environmental air pressure on these specimens to that at sea level (the air pressure at NIST/G) would be to increase $\mathrm{k}$ by a factor of 1.063 from the values measured at the elevation of Boulder. Combining these two results, we estimate that $\mathrm{kB} *=1.063 * 19.66=20.9 \mathrm{~mW} /(\mathrm{m} \cdot \mathrm{K})$ for a temperature of $297 \mathrm{~K}$ and an ambient environmental pressure equal to that at sea level. Under the same conditions, Rennex, Somers, Faison and Zarr [3] found $\mathrm{kG}=21.8 \mathrm{~mW} /(\mathrm{m} \cdot \mathrm{K})$ at an environmental air pressure of $100.1 \mathrm{kPa}$ and a temperature of $297 \mathrm{~K}$, for specimens having a density of $301 \mathrm{~kg} / \mathrm{m}^{3}$. The difference is about $1.9 \%$ and is less than the combined estimates for the experimental biases of the NIST/B $( \pm 1.5 \%)$ and NIST/G $( \pm 0.9 \%)$ apparatus. This agreement is satisfactory. Recent work by NIST/B, to be published separately, indicates that the different densities used in this comparison have little or no effect on the conclusion.

This analysis has assumed that the pressure dependence of the thermal conductivity, given by eq(2) and obtained for a specimen temperature of $318 \mathrm{~K}$, was valid for estimating the pressure dependence of $\mathrm{k}$ at $297 \mathrm{~K}$ in order to compare results obtained by different labs at different environmental pressures. While the two temperatures used are not very different, so the comparison made should be valid, the effect of temperature on the $k(P)$ correlation is presently under investigation. 


\section{RECOMMENDATIONS}

The thermal conductivity of this material is somewhat lower than that of the presently established SRM 1450b (fibrous glass board with organic binder), and the material can withstand much higher temperatures. The limiting high temperature used in this study was set by the apparatus and not by the physical properties of this material. When a suitable apparatus becomes available this material should be characterized at even higher temperatures.

The most serious disadvantage of this material in its proposed use as an SRM is its high mechanical fragility. If this material is adopted as an SRM, users will have to be cautioned to exercise great care in handling it when measuring its mass and physical dimensions, when conditioning it to proper moisture content, and when installing it in, and removing it from, measurement apparatus. The material is made from extremely fine particles, and fine airborne dust is easily generated during sawing or other machining operations. Use of a dust mask should be required of those machining the material when preparing to install it into a measurement apparatus.

The relatively low thermal conductivity of this material, its apparent stability under exposure to temperatures as high as $5000 \mathrm{C}$, its freedom from phase changes, and its inorganic composition are useful and desirable properties for a new SRM. While the correlation of thermal conductivity with temperature seems to indicate the presence of some radiative heat transfer, this radiative component seems to be relatively small in comparison to the total apparent thermal conductivity. This suggests that the total heat transfer is due mostly to conduction through the microporous solid and the entrapped gas within the pores. 


\section{REFERENCES}

[1] Hust, J.G. "Status of Thermal Conductivity Standard Reference Materials at the National Bureau of Standards", THERMAL CONDUCTIVITY 18: Proceedings of the 18th International Conference on Thermal Conductivity, Ashworth, T. and Smith, David R., Eds.; pp. 327-338 (Plenum, New York, 1985).

[2] ASTM Subcommittee C16.30. "Reference Materials for Insulation Measurement Comparisons", Thermal Transmission Measurements of Insulation, ASTM STP 660, Tye, R.P., Ed.; pp. 7-29 (ASTM, Philadelphia, 1978).

[3] Rennex, B.G., Somers, T.A., Faison, T.K., and Zarr, R.R. "Evaluation of Fumed-Silica Insulation for a Thermal Conductivity Standard Reference Material", ASTM/DoE Symposium on Insulation Materials. Testing and Applications, ASTM STP, to be published (ASTM, Philadelphia, 1989).

[4] Zarr, R.R., Somers, T.A. and Ebberts, D.F. "Room-Temperature Thermal Conductivity of Fumed-Silica Insulation for a Standard Reference Material", NBSIR 88-3847, (U.S. National Institute of Standards and Technology, June 1988).

[5] Hust, J.G., Filla, B.J., Hurley, J.A. and Smith, D.R. "An Automated High Temperature Guarded-Hot-Plate Apparatus for Measuring Thermal Conductivity of Insulation Between 300 and $750 \mathrm{~K}$ ", NBSIR 88-3089 (U.S. National Institute of Standards and Technology, May 1988 ).

[6] Hust, J.G., and Lankford, A.B. "Comments on the Measurement of Thermal Conductivity and Presentation of a Thermal Conductivity Integral Method", Int. J. of Thermophysics, 3/1, 67-76 (1982).

[7] Tye, R.P. "The Thermal Conductivity of MINK-2000 Thermal Insulation in Different Environments to High Temperatures", 9th Conference on Thermal Conductivity, CONF-691002, pp. 341-351 (U.S. Atomic Energy Commission, Div. of Technical Information, March 1970) 
Table 1. Thermal conductivity of a pair of microporous fumed-silica insulation boards with a mean density of $301 \mathrm{~kg} / \mathrm{m}$. at mean temperatures from 321 to $723 \mathrm{~K}$ (48 to $450^{\circ} \mathrm{C}$ ). Measurements were performed in air at ambient humidity and ot a pressure of $83.6 \mathrm{kPo}$ (627 Torr). using the high-temperature guorded hot plate at the National Institute of Standards and Technology in Boulder. Colorodo. Temperoture differences through the specimens were chosen to be about 10 percent of the value of the mean temperature within the specimens. The bias in values of Kmeas is estimated to be 1.5 percent ot $330 \mathrm{~K}$ and 2.5 percent at $720 \mathrm{~K}$. Deviations compare measured thermal conductivity to values of Kcalc computed from eq(1).

\begin{tabular}{|c|c|c|c|c|c|}
\hline $\begin{array}{l}\text { Thi } \\
\text { (K) }\end{array}$ & $\begin{array}{l}\text { TIo } \\
(K)\end{array}$ & $\begin{array}{c}\text { Tmeon } \\
(\mathrm{K})\end{array}$ & $\begin{array}{l}\text { Kmeos } \\
m W /(m \cdot k)\end{array}$ & $\begin{array}{c}K c a l c \\
m W /(m \cdot K)\end{array}$ & $\begin{array}{l}\text { Deviotion } \\
\text { (Percent) }\end{array}$ \\
\hline $\begin{array}{l}443.256 \\
441.168 \\
443.168 \\
445.166 \\
603.281\end{array}$ & $\begin{array}{l}403.184 \\
405.093 \\
403.099 \\
401.159 \\
543.078\end{array}$ & $\begin{array}{l}423.220 \\
423.131 \\
423.134 \\
423.163 \\
573.180\end{array}$ & $\begin{array}{l}20.999 \\
20.926 \\
20.953 \\
20.950 \\
23.604\end{array}$ & $\begin{array}{l}20.932 \\
20.930 \\
20.931 \\
20.932 \\
23.512\end{array}$ & $\begin{array}{r}0.32 \\
-0.02 \\
0.11 \\
0.09 \\
0.39\end{array}$ \\
\hline $\begin{array}{l}708.294 \\
758.146 \\
737.959 \\
735.060 \\
733.157\end{array}$ & $\begin{array}{l}637.800 \\
688.102 \\
658.086 \\
661.128 \\
663.205\end{array}$ & $\begin{array}{l}673.047 \\
723.124 \\
698.023 \\
698.094 \\
698.181\end{array}$ & $\begin{array}{l}25.958 \\
27.713 \\
26.779 \\
26.855 \\
26.860\end{array}$ & $\begin{array}{l}26.058 \\
27.625 \\
26.819 \\
26.818 \\
26.818\end{array}$ & $\begin{array}{r}-0.38 \\
0.32 \\
-0.15 \\
0.14 \\
0.15\end{array}$ \\
\hline $\begin{array}{l}713.031 \\
711.104 \\
708.141 \\
706.160 \\
681.099\end{array}$ & $\begin{array}{l}633.139 \\
635.156 \\
638.187 \\
640.261 \\
615.150\end{array}$ & $\begin{array}{l}673.085 \\
673.130 \\
673.164 \\
673.211 \\
648.125\end{array}$ & $\begin{array}{l}26.058 \\
26.071 \\
26.085 \\
26.061 \\
25.364\end{array}$ & $\begin{array}{l}26.064 \\
26.063 \\
26.061 \\
26.061 \\
25.351\end{array}$ & $\begin{array}{r}-0.02 \\
0.03 \\
0.09 \\
0.00 \\
0.05\end{array}$ \\
\hline $\begin{array}{l}653.024 \\
653.150 \\
653.151 \\
628.057 \\
605.207\end{array}$ & $\begin{array}{l}593.135 \\
593.229 \\
593.201 \\
568.134 \\
541.133\end{array}$ & $\begin{array}{l}623.080 \\
623.190 \\
623.176 \\
598.096 \\
573.170\end{array}$ & $\begin{array}{l}24.651 \\
24.625 \\
24.687 \\
23.998 \\
23.523\end{array}$ & $\begin{array}{l}24.689 \\
24.692 \\
24.692 \\
24.078 \\
23.513\end{array}$ & $\begin{array}{r}-0.16 \\
-0.27 \\
-0.02 \\
-0.33 \\
0.04\end{array}$ \\
\hline $\begin{array}{l}603.127 \\
601.125 \\
578.078 \\
550.107 \\
548.151\end{array}$ & $\begin{array}{l}543.159 \\
545.221 \\
518.148 \\
496.166 \\
498.170\end{array}$ & $\begin{array}{l}573.143 \\
573.173 \\
548.113 \\
523.137 \\
523.161\end{array}$ & $\begin{array}{l}23.521 \\
23.534 \\
22.962 \\
22.431 \\
22.509\end{array}$ & $\begin{array}{l}23.511 \\
23.511 \\
22.986 \\
22.500 \\
22.499\end{array}$ & $\begin{array}{r}0.04 \\
0.10 \\
-0.10 \\
-0.31 \\
0.04\end{array}$ \\
\hline $\begin{array}{l}546.152 \\
523.120 \\
500.134 \\
498.134 \\
496.097\end{array}$ & $\begin{array}{l}500.169 \\
473.165 \\
446.159 \\
448.130 \\
450.108\end{array}$ & $\begin{array}{l}523.161 \\
498.143 \\
473.147 \\
473.132 \\
473.103\end{array}$ & $\begin{array}{l}22.551 \\
21.992 \\
21.650 \\
21.652 \\
21.621\end{array}$ & $\begin{array}{l}22.498 \\
22.054 \\
21.647 \\
21.645 \\
21.644\end{array}$ & $\begin{array}{r}0.23 \\
-0.28 \\
0.02 \\
0.03 \\
-0.11\end{array}$ \\
\hline $\begin{array}{l}391.242 \\
393.187 \\
395.141 \\
418.205 \\
341.115\end{array}$ & $\begin{array}{l}355.150 \\
353.153 \\
351.120 \\
378.168 \\
306.888\end{array}$ & $\begin{array}{l}373.196 \\
373.170 \\
373.131 \\
398.187 \\
324.002\end{array}$ & $\begin{array}{l}20.375 \\
20.312 \\
20.364 \\
20.693 \\
19.788\end{array}$ & $\begin{array}{l}20.344 \\
20.345 \\
20.345 \\
20.623 \\
19.875\end{array}$ & $\begin{array}{r}0.15 \\
-0.16 \\
0.09 \\
0.34 \\
-0.44\end{array}$ \\
\hline $\begin{array}{l}339.181 \\
340.177 \\
337.172\end{array}$ & $\begin{array}{l}307.182 \\
306.394 \\
305.412\end{array}$ & $\begin{array}{l}323.182 \\
323.286 \\
321.292\end{array}$ & $\begin{array}{l}19.806 \\
19.898 \\
19.886\end{array}$ & $\begin{array}{l}19.868 \\
19.869 \\
19.852\end{array}$ & $\begin{array}{r}-0.31 \\
0.14 \\
0.17\end{array}$ \\
\hline
\end{tabular}


Table 2. Thermal conductivity of a pair of microporous fumed-silica insulation boards with a mean density of $301 \mathrm{~kg} / \mathrm{m}$, at a mean temperature of $318 \mathrm{~K}\left(45^{\circ} \mathrm{C}\right)$. Measurements were performed in air at ambient humidity and at pressures ranging from 40 to $83.5 \mathrm{kPa}$ (626 Torr) using the NIST/B high-temperature guarded hot plate. Temperature differences through the specimens were chosen to be about 10 percent of the value of the mean temperature within the specimens. The bias in values of kmeas is estimated to be 1.5 percent at $330 \mathrm{~K}$. Deviations compare measured thermal conductivity to values of Kcalc computed from eq (2). The highest pressure ( $83.5 \mathrm{kPo} ; 626$ Torr) is the local ambient atmospheric pressure at Boulder, Colorado.

\begin{tabular}{|c|c|c|c|c|c|c|}
\hline $\begin{array}{l}\text { Thi } \\
(\mathrm{K})\end{array}$ & $\begin{array}{l}\text { Tlo } \\
(\mathrm{K})\end{array}$ & $\begin{array}{c}\text { Tmean } \\
(K)\end{array}$ & $\begin{array}{l}\text { Kmeas } \\
m W /(m \bullet k)\end{array}$ & $\begin{array}{c}K c a l c \\
m W /(m \bullet K)\end{array}$ & $\begin{array}{l}\text { Pressure } \\
\text { (kPo) }\end{array}$ & $\begin{array}{l}\text { Deviation } \\
\text { (Percent) }\end{array}$ \\
\hline $\begin{array}{l}331.151 \\
333.152 \\
334.130 \\
331.143 \\
331.095\end{array}$ & $\begin{array}{l}305.119 \\
304.224 \\
304.259 \\
305.150 \\
305.076\end{array}$ & $\begin{array}{l}318.135 \\
318.688 \\
319.195 \\
318.147 \\
318.086\end{array}$ & $\begin{array}{l}20.070 \\
20.047 \\
19.972 \\
19.913 \\
19.626\end{array}$ & $\begin{array}{l}19.982 \\
19.982 \\
19.982 \\
19.950 \\
19.696\end{array}$ & $\begin{array}{l}83.5 \\
83.5 \\
83.5 \\
83.1 \\
80.0\end{array}$ & $\begin{array}{r}0.44 \\
0.32 \\
-0.05 \\
-0.19 \\
-0.35\end{array}$ \\
\hline $\begin{array}{l}332.209 \\
333.133 \\
334.140 \\
335.229 \\
332.142\end{array}$ & $\begin{array}{l}304.294 \\
304.090 \\
304.205 \\
304.469 \\
304.149\end{array}$ & $\begin{array}{l}318.252 \\
318.612 \\
319.173 \\
319.849 \\
318.146\end{array}$ & $\begin{array}{l}19.099 \\
19.054 \\
19.089 \\
18.447 \\
17.811\end{array}$ & $\begin{array}{l}19.107 \\
19.107 \\
19.107 \\
18.468 \\
17.779\end{array}$ & $\begin{array}{l}73.3 \\
73.3 \\
73.3 \\
66.7 \\
60.0\end{array}$ & $\begin{array}{r}-0.04 \\
-0.28 \\
-0.09 \\
-0.11 \\
0.18\end{array}$ \\
\hline $\begin{array}{l}331.164 \\
332.147 \\
331.167 \\
332.141 \\
331.121\end{array}$ & $\begin{array}{l}305.155 \\
304.151 \\
305.178 \\
304.142 \\
305.109\end{array}$ & $\begin{array}{l}318.160 \\
318.149 \\
318.173 \\
318.142 \\
318.115\end{array}$ & $\begin{array}{l}17.083 \\
17.059 \\
17.016 \\
16.275 \\
16.245\end{array}$ & $\begin{array}{l}17.041 \\
17.041 \\
17.041 \\
16.252 \\
16.252\end{array}$ & $\begin{array}{l}53.3 \\
53.3 \\
53.3 \\
46.7 \\
46.7\end{array}$ & $\begin{array}{r}0.25 \\
0.11 \\
-0.14 \\
0.14 \\
-0.04\end{array}$ \\
\hline $\begin{array}{l}332.185 \\
333.123 \\
332.142 \\
331.152 \\
332.125\end{array}$ & $\begin{array}{l}304.187 \\
303.818 \\
304.138 \\
305.167 \\
304.120\end{array}$ & $\begin{array}{l}318.186 \\
318.471 \\
318.140 \\
318.160 \\
318.123\end{array}$ & $\begin{array}{l}15.443 \\
15.376 \\
15.395 \\
17.768 \\
17.801\end{array}$ & $\begin{array}{l}15.414 \\
15.414 \\
15.414 \\
17.779 \\
17.779\end{array}$ & $\begin{array}{l}40.0 \\
40.0 \\
40.0 \\
60.0 \\
60.0\end{array}$ & $\begin{array}{r}0.19 \\
-0.25 \\
-0.12 \\
-0.06 \\
0.12\end{array}$ \\
\hline
\end{tabular}




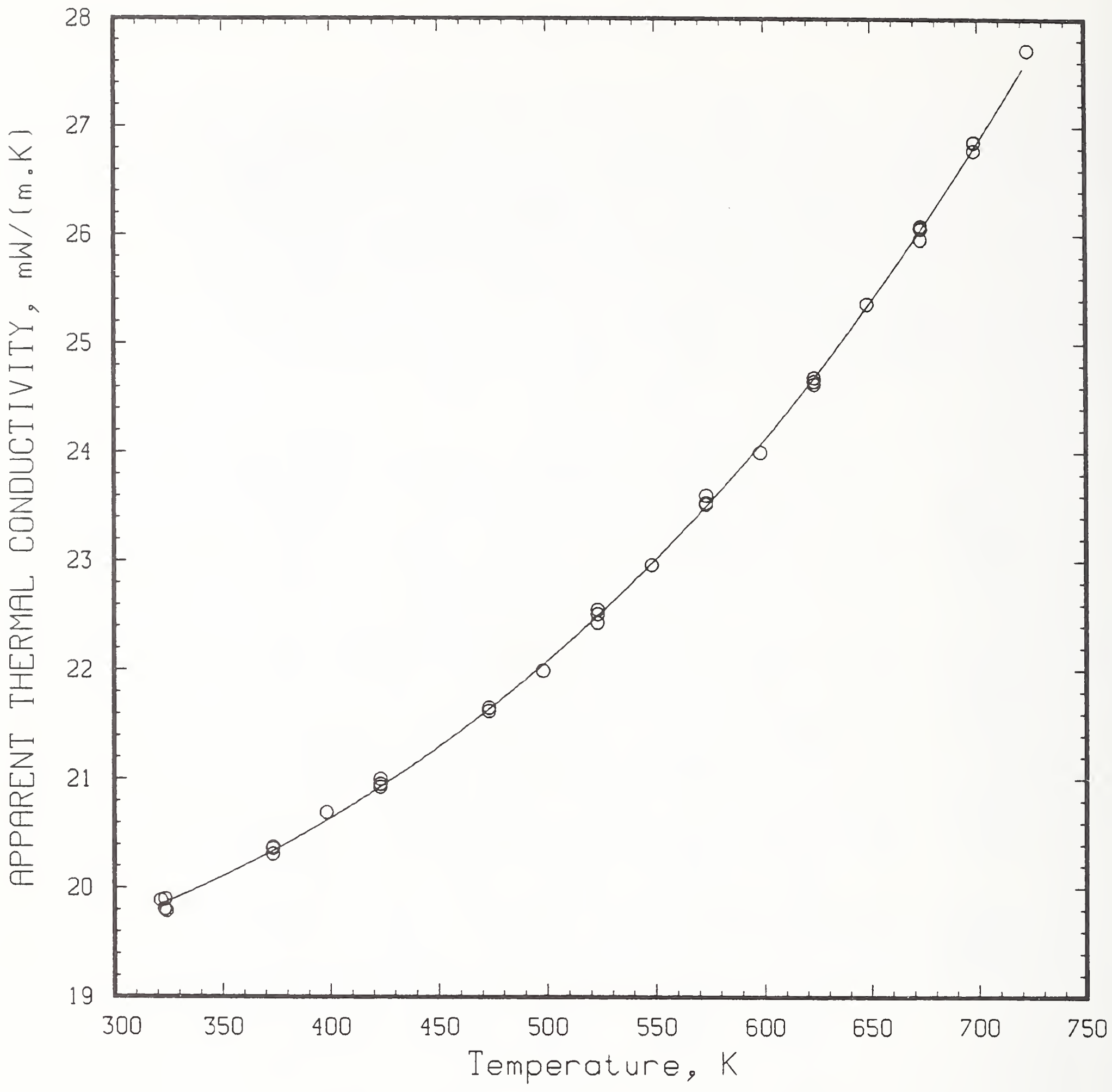

Figure 1. Thermal conductivity of a pair of microporous fumedsilica insulation boards with a mean density of $301 \mathrm{~kg} / \mathrm{m} 3$, at mean temperatures from 321 to $723 \mathrm{~K}$ ( 48 to $4500 \mathrm{C}$ ). Measurements were performed in air at ambient humidity and at a pressure of $83.6 \mathrm{kPa}$ (627 Torr) using the NIST/B high-temperature guarded hot plate. The measurement bias in values of Kmeas is estimated to be $1.5 \%$ at $330 \mathrm{~K}$, and $2.5 \%$ at $720 \mathrm{~K}$. The solid curve represents values of Kcalc, obtained using eq(1). 


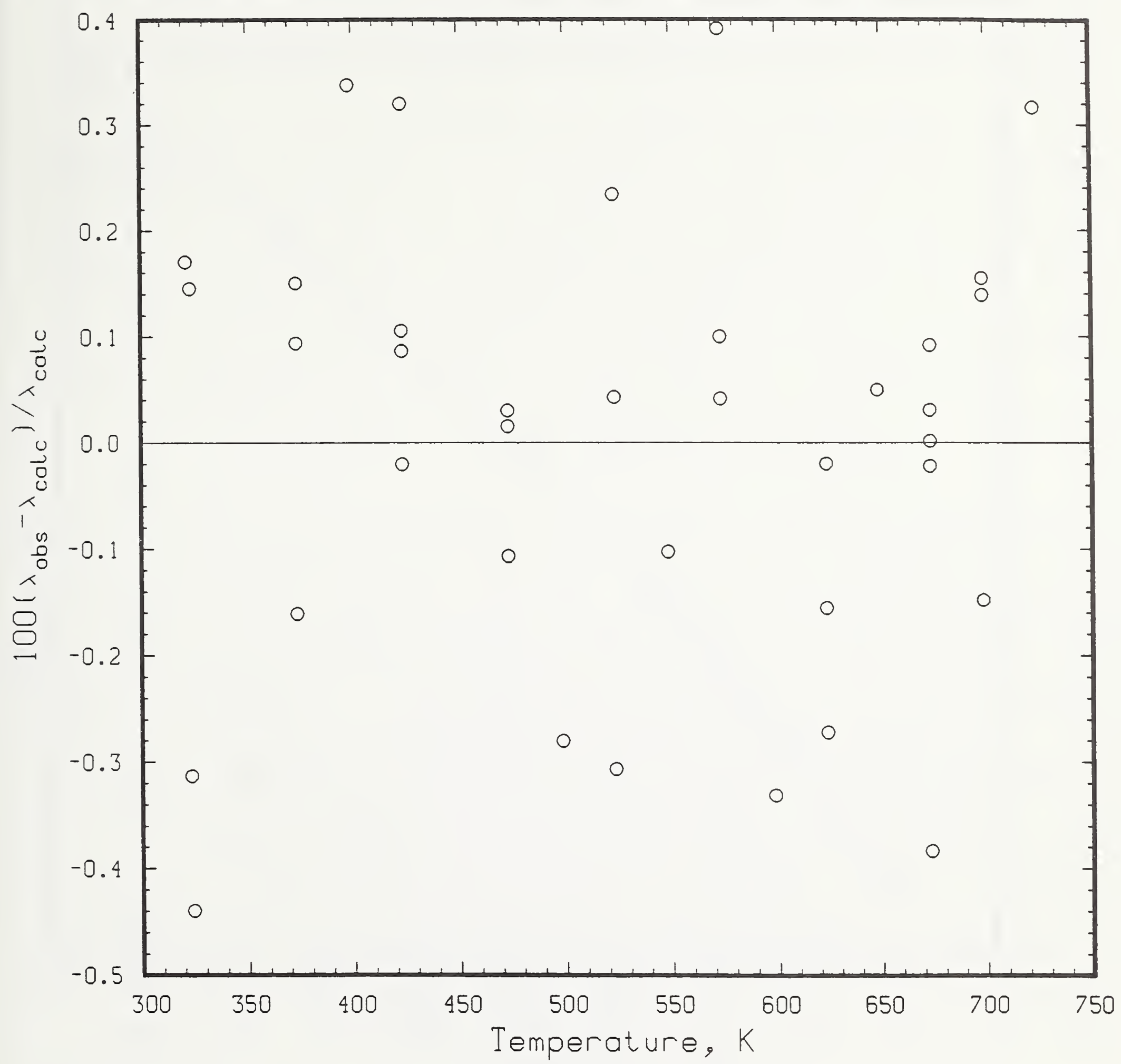

Figure 2. Deviations of thermal conductivity of microporous fumedsilica specimens from values calculated with eq(1). 


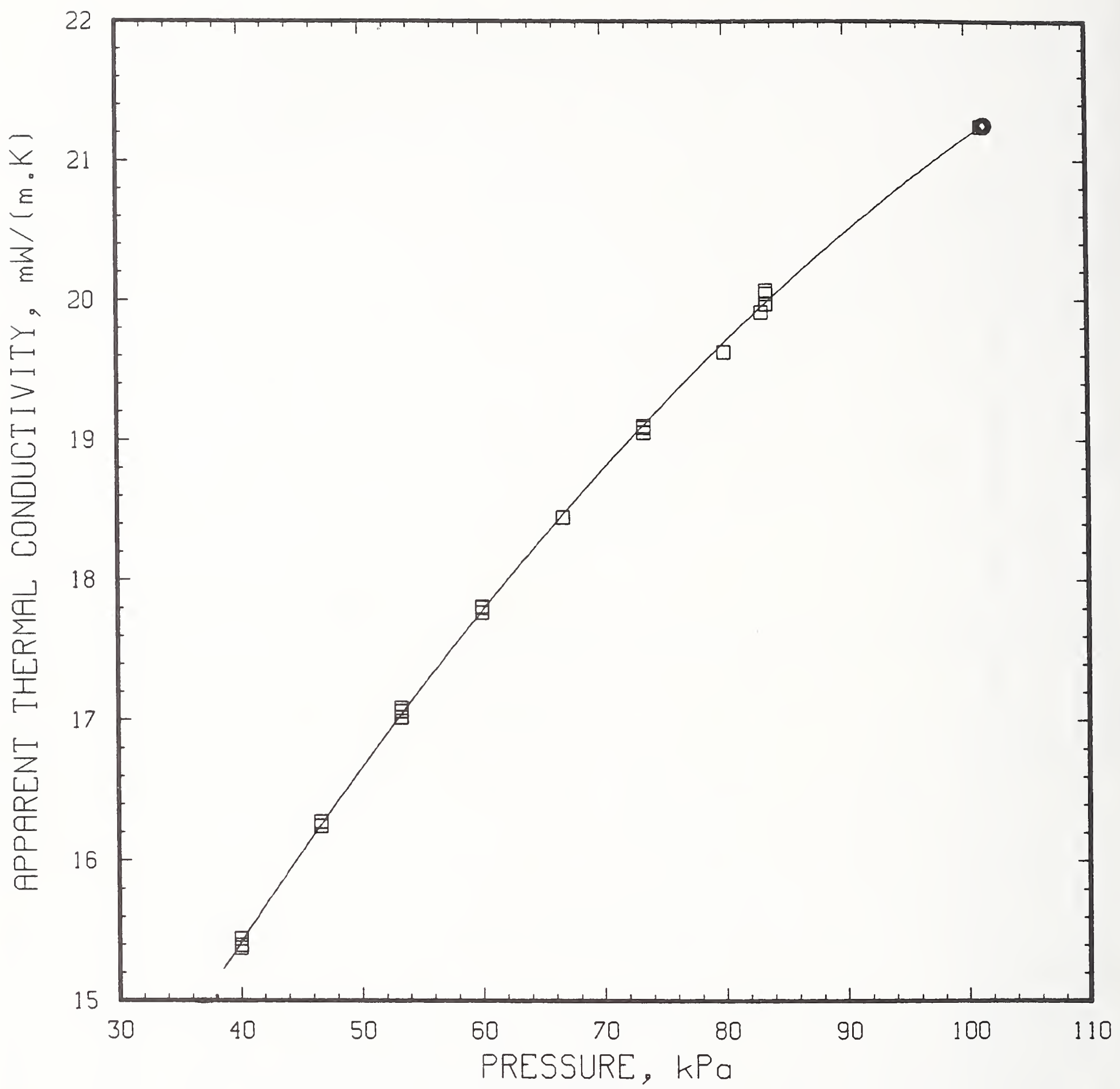

Figure 5. Extrapolated correlation of thermal conductivity with with pressure, eq(2), estimating thermal conductivivity of microporous fumed-silica insulation at sea-level atmospheric pressure $(101.3 \mathrm{kPa})$ as indicated by the open circle at the top. Mean temperature of specimens is $318 \mathrm{~K}$. 
BIBLIOGRAPHIC DATA

SHEET (See instructions)

4. TITLE AND SUBTITLE

MICROPOROUS FUMED-SILICA INSULATION BOARD AS A CANDIDATE STANDARD REFERENCE MATERIAL OF THERMAL RESISTANCE

5. $\operatorname{AUTHOR}(S)$

DAVID R. SMITH and JEROME G. HUST

6. PERFORMING ORGANIZATION (If joint or other than NBS, see instructions,

National Institute of Standards and Technology

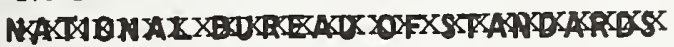

DEPARTMENT OF COMMERCE

WASHINGTON, D.C. 20234

9. SPONSORING ORGANIZATION NAME AND COMPLETE ADDRESS (Street. City, State, ZIP)

7. Contract/Grant No.

ORNL/IA-2] 428

8. Type of Report \& Period Covered

Sponored, in part, by

U.S. Department of Energy

Oak Ridge National Laboratory

Oak Ridge, NT 37830

10. SUPPLEMENTARY NOTES

$\square$ Document describes a computer program; SF-185, FIPS Software Summary, is attached.

11. ABSTRACT (A 200-word or less factual summary of most significant information. If document includes a significan bibliography or literature survey. mention it here)

Measurements of apparent thermal conductivity of microporous fumed-silica insulation board are reported in order to provide a basis for certifying it as a Standard Reference Material (SRM) of thermal resistance. These data, for a pair of specimens having a mean density of $301 \mathrm{~kg} / \mathrm{m}^{3}$, encompass a range of temperature from 321 to $723 \mathrm{~K}$ and environmental gas pressures at and below ambient atmospheric pressure (40 to $83.7 \mathrm{kPa}$ ). Detailed analyses and intercomparisons of previously published data are given. Correlations of thermal conductivity with temperature and with pressure are given which represent the data within a standard deviation of $0.2 \%$. This fumed-silica material has a thermal conductivity of $19.68 \mathrm{~mW} /(\mathrm{m} \cdot \mathrm{K})$ at $300 \mathrm{~K}$ and is suitable for use as an SRM of very low conductivity from room temperature up to temperatures beyond $720 \mathrm{~K}(450 \circ \mathrm{C})$. Great care in handling this material is necessary because of its fragility.

12. KEY WORDS (Six to twelve entries; alphabetical order; capitalize only proper names; and separate key words by semicolons) apparent thermal conductivity; density; microporous fumed silica; pressure; Standard Reference Material; SRM; temperature; thermal insulation; thermal resistance.

13. AVAILABILITY

XX Unlimited

$\square$ For Official Distribution. Do Not Release to NTIS

$\square$ Order From Superintendent of Documents, U.S. Government Printing Office, Washington, D.C. 20402.

14. NO. OF

PRINTED PAGES

XX Order From National Technical Information Service (NTIS), Springfield, VA. 2216I

\section{8}

15. Price 



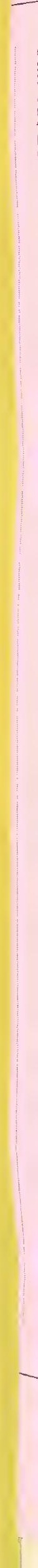

